\title{
EDITORIAL
}

\section{Working in the World}

Kit Wise

RMIT University, Australia

School of Art (Dean)

kit.wise@rmit.edu.au

At RMIT University, we pride ourselves in achieving outcomes that not only prepare for, but enhance the future careers of our graduates. 'Work ready' is a term often used to describe these qualities; those who complete our programs are seen as future leaders in, indeed the shapers of, the 'world of work'. In this sense, every graduate works in public space.

But what do we mean by the term 'work' in the field of contemporary art? Do we mean the artworks themselves; or, work as practice? Is this working for the betterment of society; or, supplying the art market, that supports artists' and gallerists' livelihoods? Do we mean work undertaken in the wider 'creative industries', an increasingly important dimension of national and international economies; or, in so-called 'cottage industries' local, often not for profit communities of practitioners that focus on felt rather than theoretical issues, to develop their own models of exchange and sustainability?

We can use the notion of 'engagement' to consider the role of public art in this world of work: engaging across disciplines, nationalities and cultures; but also with industries, communities and the world at large.

The idea of engagement is not new. 2019 marks the centenary of the founding of the Weimar State Bauhaus by Walter Gropius. Revolutionising models of art, design and architecture education at the time, the school drew on interdisciplinary ideals, international parameters and a deeply held social conscience. Gropius stated:

Our guiding principle was that design is neither an intellectual nor a material affair, but simply an integral part of the stuff of life, necessary for everyone in a civilized society. (1935)

Gropius established the archetypal Modernist school by engaging across media, disciplines, cultures, classes and genders, with a deep commitment to the material, the applied and the experimental. These aspirations ring true one hundred years later, although the models and measures have changed.

Also in 2019, the Australian Research Council published the first outcomes from a new metric for research excellent: 'Impact and Engagement' rates universities and fields of research on a low, medium, high, scale for: 
- Impact: "contribution the research made to the economy, society, environment or culture, beyond the contribution to academic research"

- Engagement: "interaction between researchers and research end-users outside of academia"

For artists seeking to engage in the public domain, how do we demonstrate value without instrumentalising creativity? How do we research in order to achieve impact but also to explore the unknown? How do we educate to achieve innovation but remain connected to history? How do we sustain a critical commentary on society whilst receiving the rewards and resourcing? What can we learn from indigenous perspectives on engagement? Does engagement allow new futures for art and design schools, or has engagement become a dirty word?

Industry has never been more keen to engage with artists. We are seeing increasing interest across all sectors in the skills developed by artists, as research into the future of work makes clear. As Tyler et al explain in their study 'I00 jobs of the future' (2019):

Almost all the reports refer to creativity, but this is often linked with 'enterprise skills and entrepreneurship', 'decision making', 'critical thinking' or 'strategic problem solving'. [...] we identified three major clusters of skills; cross disciplinary skills that marry deep knowledge of one area with breadth, with digital skills, and with a creative orientation ('learn how to code, and learn how to paint'); interpersonal skills suited to working at the technology-human interface; and adaptability in learning strategically.

Similarly, a 2016 Foundation for Young Australians report 'The New Basics' found that the proportion of (Australian) jobs that demand digital literacy has increased by $212 \%$, critical thinking by $158 \%$, creativity by $65 \%$ and presentation skills by $25 \%$. While these statistics refer to Australia, these trends resonate globally. The 2018 study for the World Economic Forum, The Future of Jobs Report, identified 'analytical thinking and innovation, active learning and learning strategies, creativity, originality and initiative' as three of the most important skills for the workforce of 2022.

The artists discussed in this special issue of the Journal of Public Space have each identified their individual response to the role of art 'working' in the world. Indeed, this edition is characterised by the diversity of practices it encompasses and how work and activism can coincide. As implied by the Bauhaus and later made overt in Rosalind Krauss' famous essay, 'Sculpture in the Expanded Field' (1979), the field of public art has expanded as never before: artists work across media, cultures, industries and economies, often simultaneously. The widening horizon of practice that this collection represents is also indicative of an increasing emphasis on collaboration between the artist and those who engage with art: embedding practice in society.

The challenge then, is not just how to engage, but what to do with that engagement, and how to collaboratively re-think the world through art. This, too, is no small undertaking; as Hannah Arendt said (1975):

There are no dangerous thoughts for the simple reason that thinking itself is such a dangerous enterprise. 
Here we find perhaps the most important work of the artist: negotiating risk to think anew. Arendt's assertion reminds us of arguably the origins of contemporary public art, the critical practices developed at a conference of artists, poets and writers in Italy in 1957. The Situationists gathered around Guy Debord's critique of capitalism in 'The Society of the Spectacle' (1967), contributing not just to the formation of an art movement but also the student-led revolution in Paris the next year. Here, art, life and work intertwined in the most impactful way.

Like Arendt, Giorgio Agamben points to the critical role of artists in 'witnessing' the events of our time, by giving voice to and making visible those who cannot speak (1999):

the value of testimony lies essentially in what it lacks; at its centre it contains something that cannot be borne witness to and that discharges the survivors of authority.

He points out that those who experience the full force of conflict, are those most likely to perish and therefore, be unable to tell their story. For artists working in the public domain, this witnessing brings events to our collective attention, urging reflection. The practices discussed in this edition of the Journal of Public Space each require this thought on the part of the viewer. Whether pursuing a dérive to find new vectors in the expanded world of work that exploit the increasingly valued status of the artist as cultural producer in economic terms; or, engaging in détournement, to redeploy the forms and functions of public space as modes of witnessing, commenting and protesting, these artists address how action can be, must be taken.

This text was drafted in Hong Kong, a city punctured by nearly six months of student-led protest. Fifty-one years after the May 1968 Paris uprising, we see a different political model contested. The city is stoic, bracing as protest, counter-protest, police and military action ripple from its administrative centre to the regions, with universities increasingly becoming the battleground. The walls of the arterial roads are a palimpsest of redacted graffiti, often several layers deep, as slogans are painted out only to remerge the next day. Long chains of hand-made paper cranes appear on walkways, made by protesters of all ages, to vanish overnight. Pedestrian bollards have been dismantled, leaving gaps like missing teeth in the urban fabric. Umbrellas protect not against rain, but tear gas and rubber bullet. Black, white and yellow have become the colours that not only mark tarmac roads, directing the flow of traffic; but are also the colours worn by those seeking to direct the flow of history, literally becoming the (their) city. An art of activism indeed.

\section{References}

Agamben, G. (1999). Remnants of Auschwitz, trans. Daniel Heller-Roazen, Zone Books: New York. Arendt, H. (1975) [20I3]. Hannah Arendt: The Last Interview and Other Conversations, Melville House: New York.

Debord, G. (1994) [1967]. The Society of the Spectacle, trans. Donald Nicholson-Smith, Zone Books: New York. 
Foundation for Young Australians (2017). The New Basics. New Work Order Series. Foundation for Young Australians: Melbourne. Retrieved from https://www.fya.org.au/report/the-newbasics/.

Gropius, W. (1965) [1935]. 'Die neue Architektur und das Bauhaus: Grundzüge und Entwicklung eine', trans. P. Morton Shand. In The New Architecture and the Bauhaus, MIT Press: Cambridge.

Rosalind Krauss, R. (1979). 'Sculpture in the Expanded Field', in October Vol. 8 (Spring, 1979), pp. 30-44. MIT Press: Cambridge.

Tytler, R., Bridgstock, R. S., White, P., Mather, D., McCandless, T., \& Grant-Iramu, M. (2019). 100 jobs of the future. Deakin University: Burwood. Retrieved from https://I00jobsofthefuture.com/report/.

World Economic Forum (2016). The future of jobs: Employment, skills and workforce strategy for the fourth industrial revolution. Global Challenge Insight Report. World Economic Forum: Geneva. Retrieved from http://www3.weforum.org/docs/WEF_Future_of_Jobs.pdf.

To cite this article:

Wise, K. (2019). Working in the World. The Journal of Public Space, 4(3), 3-6, DOI $10.32891 /$ jps.v4i3.1218 